\title{
ANALISIS PRINSIP KESANTUNAN DALAM DIALOG NARASI MATA NAJWA EPISODE COBA-COBA TATAP MUKA
}

\author{
Sely Nursita ${ }^{1}$, Rizqi Nur Amala ${ }^{2}$, Asep Purwo Yudi Utomo ${ }^{3}$ \\ ${ }^{* 1,2,3}$ Program Studi Pendidikan Bahasa dan Sastra Indonesia, Fakultas Bahasa dan Seni, Universitas \\ Negeri Semarang, Indonesia \\ e-mail: ${ }^{1}$ selynursita347@students.unnes.ac.id, ${ }^{2}$ rnamala21@students.unnes.ac.id, \\ 3aseppyu@mail.unnes.ac.id
}

\begin{abstract}
ABSTRAK
Bahasa dijadikan sebagai alat komunikasi utama yang dilakukan oleh manusia dalam menjalani kehidupan. Komunikasi tersebut harus berjalan dengan menerapkan adanya prinsip kesantunan berbahasa, tak terkecuali dalam tuturan pada program televisi talkshow. Tujuan penelitian ini adalah untuk mengetahui serta mendeskripsikan penggunaan prinsip kesantunan berbahasa dalam dialog narasi Mata Najwa episode "Coba-Coba Tatap Muka". Metode yang digunakan dalam penelitian kali ini ialah dengan metode deskriptif kualitatif. Dengan teknik pengumpulan data berupa metode simak dan penulisan. Sumber data diperoleh dari data lisan yang berwujud tuturan dalam seri diskusi Najwa Shihab dengan para narasumbernya dengan memperhatikan kaidah prinsip kesantunan berbahasa. Hasil penelitian menunjukkan bahwa terdapat prinsip kesantunan berbahasa yang dibuktikan dengan ditemukannya pematuhan maksim-maksim prinsip kesantunan berbahasa. Ditemukan data sebanyak 22 maksim prinsip kesantunan berbahasa yang terbagi atas maksim kebijaksanaan sebanyak 4 tuturan, maksim kedermawaan sebanyak 3 tuturan, maksim penghargaan sebanyak 3 tuturan, maksim kesederhanaan sebanyak 3 tuturan, maksim pemufakatan sebanyak 5 tuturan, dan maksim kesimpatian sebanyak 4 tuturan. Penelitian ini diharapkan mampu dipahami oleh pembaca dan dijadikan sebagai sumber informasi atau rujukan untuk melakukan penelitian prinsip kesantunan berbahasa ke depannya.
\end{abstract}

Kata kunci: Kesantunan berbahasa, tuturan, talkshow.

\begin{abstract}
ABSTRACK
Language is used as the main communication tool used by humans in living life. The communication must run by applying the principle of politeness in language, there is no speech in the speech on the television talkshow program. The purpose of this study was to identify and describe the principles of using language politeness in the narrative dialogue of Mata Najwa episode "Try Face to Face". The method used in this research is descriptive qualitative method. With data collection techniques in the form of listening and writing methods. The source of the data was obtained from oral data in the form of speech in the discussion series of Najwa Shihab with the speakers by paying attention to the rules of language politeness. The results of the study indicate that there is a principle of politeness in language as evidenced by the finding of compliance with the maxims of the principle of politeness in language. There were 22 maxims of politeness principles in language which were divided into 4 utteances, 3 utterances of generosity maxim, 3 utterances of appreciation maxim, 3 utterances of simple maxim, 5 utterances of consensus maxim, and 4 utterances of sympathy maxim. This research is expected to be accessible to readers and used as a source of information or reference to conduct research on language politeness into its application.
\end{abstract}

Keywords: Language politeness, speech, talkshow.

\section{PENDAHULUAN}

Manusia pada dasarnya merupakan makhluk sosial yang dalam kehidupannya membutuhkan komunikasi. Kegiatan komunikasi merupakan kegiatan yang tidak bisa dilepaskan dalam aktivitas kegiatan manusia. Pada kehidupan manusia, komunikasi bertujuan untuk memberikan atau mendapatkan informasi tentang suatu hal yang menjadi fokus dalam kegiatan komunikasi [1]. Saat melakukan kegiatan komunikasi akan ada peristiwa timbal balik, seperti bertanya dan menjawab, meminta dan memberi memerintah dan melakukan, memberi tahu dan menanggapi [2]. Dalam 
melangsungkan kegiatan komunikasi, tentunya diperlukan dua subjek agar kegiatan komunikasi dapat dilakukan. kedua subjek ini biasa disebut dengan penutur dan mitra tutur di mana keduanya dalam melakukan komunikasi akan saling merespon untuk memberikan sebuah informasi. Kegiatan komunikasi dapat berlangsung jika penutur dan mitra tutur dapat saling memberikan respon dan ikut terlibat aktif dalam proses komunikasi [3]. Untuk itu, antara penutur dan juga mitra tutur, keduanya harus saling memiliki keterampilan berbahasa dan juga penggunaan bahasa yang baik agar tuturan yang ingin disampaikan dapat tersampaikan dan. Sebaliknya, jika penutur maupun mitra tutur tidak menggunakan dan memahami bagaimana penggunaan bahasa yang tepat, maka kegiatan komunikasi dapat dikatakan tidak berjalan dengan efektif , sehingga akan menimbulkan kesalahpahaman antara penutur dan mitra tutur [4].

Selain pemahaman tentang penggunaan bahasa yang tepat dalam berkomunikasi, penutur dan mitra tutur juga harus memperhatikan kesantunan berbahasa dalam setiap tuturannya. Kesantunan sendiri dikatakan sebagai wujud dari budi pekerti serta tingkah laku dalam diri seseorang, sedangkan kesantunan berbahasa merupakan wujud berbahasa seseorang untuk memberi kedekatan jarak sosial antara penutur dengan mitra tutur. Pendapat lain mengatakan bahwa kesantunan berbahasa merupakan kegiatan berkomunikasi yang dilakukan secara verbal atau nonverbal guna mengungkapkan pikiran dan juga gagasan [5]. Kesantunan berbahasa dapat ditunjukkan dengan memberikan kesan santun yang diperlihatkan dalam bentuk pemilihan penggunaan kata, bentuk dari kalimat, dan ragam bahasa yang digunakan [6]. Selain itu, kesantunan juga dapat diperlihatkan dalam wujud ekspresi, pola sikap, dan gestur tubuh [7]. Tuturan dalam berbahasa dapat dikatakan santun apabila penutur menggunakan pemilihan kata yang santn, tidak mengandung unsur ejekan, tidak adanya usnur memerintah, dan tentunya mengandung bahasa yang terkehan menghormati orang lain [8]. Dalam kegiatan komunikasi, tentunya kesantunan berbahasa merupakan keterampilan yang harus dimiliki oleh setiap penutur bahasa agar dapt melakukan kegiatan interaksi dengan penutur lain dan kesantunan berbahasa menjadi suatu bagian yang penting agar seseorang dapat saling bertukar informasi secara lebih baik dan teratur [9].

Kesantunan berbahasa memiliki tiga aturan yang dapat memenuhi kesantunan dalam berbahasa, yaitu 1) tidak adanya unsur paksaan, 2) bahasa yang disampaikan harus tegas dan tidak diperkenankan untuk membuat mitra tutur merasa sulit merespon, 3) menjadikan lawan tutur sebagai teman [10]. Kesantunan berbahasa ini dapat dilihat misalnya pada saat seseorang tidak menggunakan bahasa sehari-hari kepada seorang pejabat di kantornya, maka seseorang itu telah menunjukkan hormat kepada pejabat yang menjadi lawan tuturnya [11]. Kesantunan berbahasa memiliki syarat kesantunan yang harus ditaati oleh penutur, di mana kriteria ini nantinya akan menuntun penutur untuk dapat menciptakan tuturan yang efektif serta terhindar dari kesalahpahaman antara penutur [12]. Kesantunan berbahasa dalam pragmatik memiliki beberapa prinsip atau yang biasa disebut dengan prinsip kesantunan berbahasa. Ada teori tentang prinsip kesantunan berbahasa yang terkenal, yaitu prinsip kesantunan berbahasa menurut Leech di mana ia mengungkapkan bahwa setiap interaksi para penutur memerlukan prinsip kesantunan yang di dalamnya terdiri dari 6 maksim. Enam maksim tersebut adalah 1) maksim kebijaksanaan (tact maxim), 2) maksim kedermawanan (generosity maxim), 3) maksim penghargaan (approbation maxim), 4) maksim kesederhanaan (modesty maxim), 5) maksim pemufakatan (agreement maxim), 6) maksim kesimpatian (sympath maxim).

Kesantunan berbahasa dalam komunukasi menjadi salah satu hal yang disorot dalam era globalisasi seperti ini. Apalagi, di era ini banyak penutur yang mencampuradukkan bahasa gaul dalam melakukan komunikasi dengan teman, orang tua, guru, dan bahkan orang yang belum dikenalinya, sehingga penggunaan bahasa yang dituturkan cenderung kurang santun (Ni'am \& Utomo, 2019). Salah satu media yang menjadi sorotan mengenai kesantunan dalam berkomunikasi adalah media televisi. Media televisi merupakan media yang saat ini masih menjadi kegemaran masyarakat untuk mendapatkan informasi ataupun sekedar menikmati hiburan. Dalam tayangan televisi akan banyak ditemukan komunikasi yang terjalin antara pembawa acara suatu talkshow dengan narasumber (Musthofa \& Utomo, 2021). Pada penelitian kali ini, penulis menjadikan acara talkshow Mata Najwa sebagai media dalam menemukan data yang nantinya akan menjadi bahan analisis. Mata Najwa merupakan acara talkshow yang sampai saat ini masih menjadi kegemaran banyak orang. Topik pembicaraannya selalu mengangkat isu-isu yang sedang menjadi polemik 
dikalangan masyarakat, seperti topik tentang percobaan tatap muka yang saat ini masih menjadi pro dan kontra bagi peserta didik, pendidik, dan juga pemerintah sebagai pemangku utama dalam sektor pendidikan. Untuk itu pada kesempatan kali ini, penulis tertarik untuk menjadikan acara talkshow Mata Najwa yang berjudul "Coba-Coba Tatap Muka" sebagai bahan analisis dalam menemukan prinsip kesantunan serta mengaitkannya dengan 6 maksim yang diutarakan oleh Leech.

Ada beberapa penelitian yang relevan terkait penelitian tentang Prinsip Kesantunan Berbahasa, seperti penelitian yang dilakukan oleh Hidayat Nur Septiadi (2020) berjudul "Kesantunan Berbahasa pada Acara Talkshow Hitam Putih Trans 7 Episode Solena Chaniago Seorang Transgender dengan Biaya 1 Miliar" yang dalam analisisnya penulis menyimpulkan bahwa acara talkshow telah memenuhi prinsip kesantunan berbahasa, yaitu tact maxim, generosity maxim, approbation maxim, modesty maxim, agreement maxim, dan sympathy maxim. Penelitian oleh Qorita Fitria Yuni (2013) berjudul "Kesantunan Berbahasa dalam Mata Najwa (Tinjauan Pragmatik)" dalam penelitian ini penulis menganalisis prinsip kesantunan berbahasa dengan menjelaskan bentukbentuk dari kesantunan berbahasa, yaitu bentuk deklaratif, bentuk interogatif, dan bentuk imperatif. Penelitian oleh Rika Astuti, dkk (2012) berjudul "Kesantunan Berbahasa dalam Talkshow Neo Democrazy di Metro TV" dalam analisisnya penulis tidak hanya membahas mengenai prinsip kesantunan yang ada pada acara talkshow tersebut, tetapi penulis juga menjabarkan mengenai strategi bertutur yang digunakan dalam talkshow Neo Democrazy. Beberapa penelitian di atas memiliki kesamaan, yaitu kajiannya yang sama-sama terfokus pada analisis prinsip kesantunan berbahasa. Di dalam penelitian ini, penulis akan terfokus pada analisis prinsip kesantunan dalam 6 maksim yang diutarakan oleh Leech, yaitu maksim kebijaksanaan, maksim kedermawanan, maksim penghargaan, maksim kesederhanaan, maksim pemufakatan, maksim kesimpatian dengan menggunakan dialog narasi yang ada dalam acara talkshow Mata Najwa yang berjudu "Coba-Coba Tatap Muka". Dari tinjauan pustaka yang telah penulis lakukan, penelitian mengenai prinsip kesantunan yang ada dalam dialog narasi Mata Najwa "Coba-Coba Tatap Muka" belum pernah dilakukan, sehingga hal ini menjadi dasar pertimbangan penulis untuk melakukan penelitian mengenai prinsip kesantunan yang ada dalam dialog narasi Mata Najwa "Coba-Coba Tatap Muka" dan penulis menyimpulkan bahwa penelitian ini layak untuk dilakukan.

Penelitian ini bertujuan untuk mengetahui penggunaan prinsip kesantunan yang terdapat dalam acara Mata Najwa episode "Coba-Coba Tatap Muka", menilai sejauh mana kesantunan seseorang dalam melakukan komunikasi, menganalisis serta mendeskripsikan prinsip kesantunan dengan mengaitkannya pada enam maksim yang diungkapkan oleh Leech. Adapun manfaat dari penelitian ini adalah sebagai bahan materi dalam pembelajaran prinsip kesantunan berbahasa, sebagai bahan rujukan untuk penelitian selanjutnya terkait dengan pembahasan prinsip kesantunan, memberikan pemahaman terkait subbahasan prinsip kesantunan berbahasa, khususnya pemahaman tentang maksim maksim yang ada, menambah referensi kajian ilmu kebahasaan pragmatik.

\section{METODOLOGI PENELITIAN}

Penelitian kali ini menggunakan metode deskriptif kualitatif. Metode kualitatif merupakan suatu prosedur penelitian yang menentukan hasil berupa data deskripsi kata-kata tertulis ataupun lisan dan orang-orang ataupun perilaku yang sedang diamati. Atau dengan kata lain, metode deskriptif kualitatif dilakukan dengan mendeskripsikan data-data yang diperoleh selama proses penelitian. Penelitian kualitatif ini dilakukan dengan tujuan untuk memperoleh data berupa fakta terkait fenomena kesantunan berbahasa dalam tuturan. Selain itu, peneliti juga menggunakan pendekatan teoretis berupa kajian pendekatan pragmatik yang digunakan untuk memperkuat data analisis kesantunan berbahasa. Pendekatan metodologis berupa analisis deskriptif kualitatif dan pendekatan teoretis berupa analisis studi pragmatik digunakan untuk menemukan maksud dari datadata analisis pragmatik yang didapatkan [17].

Data pada penelitian kali ini berupa tuturan yang dilakukan oleh penutur dan lawan tutur yang terdapat dalam sumber data, tentunya tuturan tersebut berkaitan dengan penerapan prinsip kesantunan berbahasa. Sumber data dalam penelitian ini diperoleh dari tuturan-tuturan yang ada dalam acara talkshow Mata Najwa episode "Coba-Coba Tatap Muka". Adapun metode dan teknik 
yang digunakan dalam pengumpulan data penelitian ialah dengan metode simak dengan teknik simak bebas catat dan teknik simak. Metode simak dilakukan dengan memperhatikan tuturan-tuturan yang ada dalam acara talkshow Mata Najwa episode "Coba-Coba Tatap Muka". Teknik simak bebas libat cakap digunakan oleh peneliti karena peneliti hanya berperan sebagai pemerhati data sehingga tidak terlibat langsung dalam peristiwa tuturan. Adapun untuk teknik catat, peneliti melakukan kegiatan mencatat data-data penting berupa tuturan yang berhubungan dengan prinsip kesantunan berbahasa dalam sumber data yang bersangkutan.

Analisis data dalam penelitian kali ini menggunakan metode normatif yang digunakan sebagai acuan untuk mencocokan data yang didapatkan dengan aturan-aturan prinsip kesantunan berbahasa. Metode normatif ini digunakan sebagai patokan atau tolak ukur untuk mengetahui santun tidaknya tuturan berdasarkan prinsip kesantunan berbahasa Leech yang terdiri dari enam maksim kesantunan berbahasa.

Langkah-langkah analisis data yang peneliti lakukan dalam penelitian ini ialah sebagai berikut: (1) menyimak tayangan acara talkshow Mata Najwa episode "Coba-Coba Tatap Muka"; (2) mencatat data yang telah ditemukan dalam buku pengumpulan data yang telah disiapkan; (3) menganalisis data yang telah terkumpul dengan mencocokkannya pada setiap maksim yang ada pada prinsip kesantunan berbahasa; (4) menyimpulkan hasil penelitian.

\section{HASIL DAN PEMBAHASAN}

\section{Hasil Penelitian}

Berdasarkan hasil dari analisis yang telah peneliti lakukan pada acara talkshow Mata Najwa episode "Coba- Coba Tatap Muka", ditemukan sejumlah 22 pematuhan maksim dalam prinsip kesantunan yang digunakan, baik oleh narasumber ataupun pembawa acara. Jumlah ini terbagi atas persebaran beberapa maksim, yaitu maksim kebijaksanaan sebanyak 4, maksim kedermawanan sebanyak 3, maksim penghargaan sebanyak 3, mksim kesederhanaan sebnayak 3, maksim pemufakatan sebanyak 5, dan maksim kesimpatian sebanyak 4. Data kesantunan ini telah memenuhi standar pematuhan prinsip kesantunan dalam berkomunikasi dan dapat dikatakan bahwa antara narasumber dan pembawa acara dapat menciptakan sebuah pola komunikasi yang santun dan mengedepankan kesantunan dalam bertindak tutur, meskipun mereka membahas isu dan juga permasalahan yang pro dan kontra dikalangan masyarakat yang tentunya banyak mengandung beragam argumentasi kuat dari narasumber.

\section{Pembahasan}

Berdasarkan hasil dari analisis yang telah peneliti lakukan pada acara talkshow Mata Najwa episode "Coba- Coba Tatap Muka", ditemukan beberapa penggunaan maksim dari prinsip kesantunan berbahasa dengan analisis sebagai berikut.

\section{Maksim Kebijaksanaan/ Kearifan}

Maksim kebijaksanaan merupakan maksim yang menghendaki peserta tuturan agar dapat memberikan keuntungan bagi pihak lain dan senantiasa mengurangi keuntungan bagi diri sendiri [18]. Dengan ini, setiap orang yang melakukan tuturan dengan senantiasa melaksanakan hingga berpegang pada maksim kebijaksanaan, mereka dapat digolongkan sebagai peserta tuturan yang santun. Penggunaan maksim kebijaksanaan pada acara talkshow Mata Najwa dapat dilihat pada data berikut.

- $\quad$ Najwa Shihab : "tapi sebelumnya saya juga akan memperkenalkan yang hadir di studio Mata Najwa untuk memberikan konteks dan juga berbincang soal berbagai permasalahan. Ada sekjen kemendikbud ristek, Suharti. Selamat malam ibu Suharti”

$\begin{array}{ll}\text { Suharti } & : \text { "selamat malam mba Nana" } \\ \text { Najwa Shihab } & \text { : "terima kasih sudah bersedia hadir di Mata Najwa" } \\ \text { Suharti } & \text { : "tentu mba" }\end{array}$


Konteks: Najwa menyapa narasumber yang hadir di studio, yaitu sekjen kemdikbud ristek, Ibu Suharti yang nantinya akan menjadi narasumber dalam sesi diskusi mengenai coba-coba tatap muka.

Tidak tutur yang dilakukan oleh Najwa Shihab kepada Suharti merupakan bentuk penerapan kesantunan berbahasa pada maksim kebijaksanaan. Hal ini karena Najwa berusaha untuk mengurangi kerugian narasumbernya dengan memperkenalkan Suharti selaku sekjen kemdikbud ristek, sebelum Najwa mengajaknya untuk berbincang. Selain itu, tak lupa pula Najwa mengucapkan rasa terima kasih kepada Suhartini karena baliau sudah mau bersedia hadir untuk berbincang mengenai pembelajaran tatap muka bersama Najwa Shihab dan juga orang tua murid.

- $\quad$ Ganjar: "kasusnya mulai turun, relatif secara skilogis lebih aman. Tapi kita tidak boleh abai, sehingga dari segi prosedur selama dua hari saya cek terus menerus."

Konteks: Ganjar menanggapi atas pertanyaan dari Najwa yaitu berkaitan dengan kondisi saat ini jika memungkinkan untuk dilakukan sekolah tatap muka.

Ganjar menanggapi bahwa saat ini kasus Covid-19 di Jawa Tengah mulai menurun sehingga bisa dikatakan bahwa kondisi sekarang relatif secara skilogis lebih aman untuk selanjutnya dilakukan kegiatan sekolah tatap muka. Namun, Ganjar mengatakan bahwa kita tidak boleh abai dan terus waspada, ia pun selalu mengecek secara terus menerus apakah sekolah tatap muka ini benar-benar aman untuk dilakukan. Tanggapan dari Ganjar tersebut kiranya mencerminkan maksim kebijaaksanaan yang ditunjukkan dengan sikap atau perilaku beliau yang terus mengecek perkembangan Covid-19, hal tersebut dilakukannya untuk memastikan keselamatan para masyarakat khususnya yang ada di Jawa Tengah. Dengan begitu, Ganjar telah mengusahakan untuk memaksimalkan keuntungan pihak lain.

\section{Maksim Kedermawanan}

Peserta tuturan dikatakan santun apabila mereka senantiasa meminimalisir keuntungan dan memaksimalkan kerugian bagi diri sendiri. Kesantunan ini dapat dilihat pada saat seorang penutur mencoba memberikan atau menambah beban bagi diri sendiri, seperti menawarkan bantuan yang memberikan keuntungan bagi mitra tutur dengan ini peserta tuturan dapat memberikan kesan hormat antara peserta tuturan [19]. Selain itu, agar kesan kedermawanan dapat diperlihatkan dalam kegiatan komunikasi, peserta tuturan hendaklah tidak menyombongkan diri sendiri [20]. Penggunaan maksim kedermawanan pada acara talkshow Mata Najwa terlihat pada data berikut.

Najwa Shihab : "siapa yang mau ngaku kalo sekolah online kebanyakan ngantuknya. Ayo gapapa, walaupun malam ini didenger kepala sekolah gapapa, ngomongnya di Mata Najwa kok kakak yang tanggung jawab. Kalo ada yang dihukum kakak yang tanggung jawab".

Konteks: Najwa memberikan pertanyaan kepada setiap murid mengenai keluhan yang mereka alami selama menjalani pembelajaran jarak jauh.

Data di atas, menunjukkan adanya penggunaan maksim kedermawanan oleh Najwa Shihab. Terlihat saat Najwa menanyakan perihal keluhan mengantuk pada peserta didik saat menjalani pembelajaran jarak jauh dan Najwa meminta peserta didik untuk mengatakan sejujurnya tanpa takut jikalau didengar oleh kepala sekolah mereka karena Najwalah yang akan bertanggung jawab terhadap jawaban mereka. Adanya perilaku untuk bertanggung jawab atas jawaban dari peserta didik ini menandakan bahwa Najwa sedang mengurangi kerugian orang lain, yaitu peserta didik dan ia sedang berusaha menambah beban dalam diri Najwa sendiri.

Harti: "kami menyadari bahwa belum semua sekolah yang memberikan laporan apakah sudah tersedia sanitasi. Jadi wajar kalau orang tua berpikir bahwa resikonya masih tinggi."

Konteks: Najwa menanyakan bahwa apakah sudah semua sekolah siap dalam menyambut para peserta didik untuk belajar mengajar di sekolah kembali. 
Dari pertanyaan Najwa, kemudian Harti menanggapi bahwa pihak pemerintah menyadari belum semua sekolah memberikan laporan mengenai apakah sudah tersedia sanitasi yang lengkap. Untuk itu wajar kalua orang tua berpikir bahwa resikonya masih sangat tinggi jika dilakukan kegiatan sekolah tatap muka. Berdasarkan hal tersebut, menunjukkan adanya maksim kedermawaan, dimana adanya upaya meminimalkan kerugian pihak lain, tetapi memaksimalkan keuntungan yang akan diperoleh pihak lain. Harti mengatakan bahwa wajar bila orang tua merasa khawatir, itu tandanya Harti menghargai serta menghormati keputusan orang lain. Tanpa pernah memaksa kehendak dari pihak manapun. Harti menyadari bahwa upaya yang dilakukan pemerintah memang belum maksimal dalam hal persiapan sekolah tatap muka.

\section{Maksim Penghargaan}

Peserta tuturan dapat dikatakan santun apabila saat bertutur mereka senantiasa memberikan penghargaan atau pujian antara peserta tuturan. Peserta tuturan hendakya menghindari sikap saling megejek, mencaci, dan merendahkan [21]. Dengan adanya maksim ini, peserta tuturan dapat saling menghargai dan menghormati antara peserta tuturan dengan memberikan sebuah pujian atau apresiasi [19]. Penggunaan maksim penghargaan pada acara talkshow Mata Najwa terlihat pada analisis data berikut.

\section{- Najwa Shihab : "emang apa sih enaknya upacara?” \\ Raisa : "bisa hormat ke bendera" \\ Najwa Syihab : "hebat kamu bisa seneng hormat bendera, keren"}

Konteks: Najwa menanyakan pepada peserta didik mengenai apa yang mereka kangenin selama kegiatan tatap muka di sekolah dan disusul oleh jawaban dari salah satu peserta didin bernama Raisa.

Data di atas, menunjukan adanya penggunaan maksim penghargaan. Terlihat saat Najwa menanyakan kepada peserta didik mengenai apa yang mereka kangenin selama kegiatan tatap muka di sekolah lalu disusul jawaban oleh salah satu peserta didik yang bernama Raisa. Ia mengatakan bahwa ia rindu upacara karena ia senang hormat kepada bendera. Hal ini sontak membuat Najwa kaget karena biasanya beberapa siswa justru malas jika mengikuti upacara bendera. Dengan ini Najwa langsung memberikan penghargaan atau pujian kepada Raisa dengan mengatakan bahwa Raisa hebat karena ia senang hormat kepada bendera merah putih.

- Najwa Shihab : "jadi waktu mengajar ke rumah-rumah seberapa jauh itu Bu? Naik gunungnya"

Tri

turunnya itu yang uji nyali",

: "ya lumayan jauh, tapi bisa pakai motor. Cuma naiknya bisa Najwa Shihab : "luar biasa para guru nih"

Konteks: Najwa menanyakan kepada narasumbernya yang merupakan salah satu guru SD di Kebumen yang harus rela mengajar dari rumah ke rumah meskipun berbagai rintangan dihadapinya.

Ibu Tri menanggapi pertanyaan dari Najwa bahwa perjalanan yang ia tempuh ketika mengajar para siswanya dari rumah ke rumah tidaklah mudah. Terlebih desa mereka memiliki aksen jalan yang lumayan sulit dengan tanjakan seperti naik ke gunung. Bu Tri mengatakan bahwa sebenarnya bisa dilalui pakai motor, hanya saja naiknya bisa tapi turunya uji nyali. Atas tanggapan bu Tri tersebut, Najwa mengapresiasi atau memberikan penghargaan atas segala usaha dan upaya yang dilakukan oleh para guru dalam menjalankan tugasnya. Najwa memberikan apresiasi yang ditunjukkan dengan ungkapan "luar biasa para guru nih". Dan diakhir perbincangan Najwa juga menyampaikan ucapan terima kasih atas cerita dari bu Tri dan mendoakan agar selalu diberikan kesehatan. Dari perbincangan tersebut, terlebih yang diungkapkan oleh Najwa menggambarkan adanya maksim penghargaan atau pujian yang diberikan untuk pihak lain. 


\section{Maksim Kesederhanaan}

Peserta tuturan dapat dikatakan santun apabila mereka mampu memaksimalkan rasa ketidakhormatan tehadap diri sendiri dengan bersikap merendah dan menghindari pujian bagi diri sendiri serta berikan kecaman bagi diri sendiri [22]. Penggunaan maksim kesederhanaan dalam acara talkshow Mata Najwa terlihat pada analisis data berikut.

- Najwa Shihab : "kamu kangen upacara beneran?"
Raisa "iya ka”
Najwa Shihab : "kalo ka Najwa sih upacara dulu gak seneng. Hebat banget kamu ya."

Konteks: Najwa menanyakan kepada Raisa apakah ia benar-benar kangen terhadap upacara bendera.

Data di atas menunjukkan adanya penggunaan maksim kesederhanaan. Najwa mengatakan bahwa dahulu ia tidak senang jika mengikuti upacara bendera. Berbeda dengan Riasa yang sangat suka jika mengikuti upacara bendera di ssekolah. Hal ini menunjukkan bahwa Najwa sedang berusaha untuk mengurangi pujian terhadap dirinya sendiri dan menambah pujian bagi orang lain.

- $\quad$ Nisa : "bapak, Ibu, dan daerah bantu kami juga untuk memastikan bahwa resiko penularan di sekolah itu semakin berkurang."

Konteks: Nisa menanggapi atas pertanyaan "apakah resiko penularan Covid-19 di sekolah benar-benar sudah teratasi?"

Berdasarkan tuturan di atas menunjukkan adanya maksim kesederhanaan atau kerendahan hati yang ditunjukkan dengan jawaban Nisa mengenai perlunya dukungan Bapak, Ibu dan daerah untuk ikut berpartisipasi dalam memastikan bahwa resiko penularan Covid-19 di sekolah akan semakin berkurang. Nisa menyadari bahwa peran pemerintah atau pejabat yang berwenang saja tidak cukup untuk mengatasi persoalan, melainkan semua lapisan masyarakat harus saling membantu satu sama lain. Hal tersebut menunjukkan kesederhanaan Nisa yang mengakui bahwa segala persoalan tidak bisa diatasi hanya dengan beberapa orang, itu artinya ia telah menunjukkan sikap meminimalkan pujian terhadap dirinya sendiri.

\section{Maksim Kesepakatan}

Maksim kesepakatan menekankan pada setiap peserta tuturan agar dapat meminimalkan rasa ketidaksetujuan dalam berkomunikasi di antara penutur (Nisa, 2016). Dalam maksim ini, usahakan agar ketidakkesepakatan antara diri dan orag lain terjadi sedikit mungkin (Leech, 1993). Setiap peserta tuturan hendaknya saling membina kecocokan dan kemufakatan dalam setiap tuturannya (Rahardi, 2008). Penggunaan maksim kesepakatan pada acara talkshow Mata Najwa dapat dilihat pada analisis data berikut.

Najwa Shihab : "jadi kalo sekarang sudah mulai pembelajaran tatap muka, walaupun baru percobaan dibeberapa daerah. Kalo ada kesempatan itu Bu Herli dan Bu Ida langsung mau ya anak biar langsung tatap muka saja, setuju tatap muka?"”

Wali Murid : "iya iya mba Nana setuju walaupun seminggu misalnya hanya 2-3 kali yang penting anak-anak suka sekolah, kenal dengan lingkungan sekolah dan teman temannya"

Konteks: Najwa menanyakan kepada wali murid, yaitu Ibu Herli dan Ibu Ida mengenai persetujuan sekolah tatap muka.

Data di atas, menunjukkan adanya penggunaan maksim pemufakatan. Terlihat saat Najwa mengajukan pertanyaan persetujuan kepada Ibu Herli dan Ibu Ida jikalau ada kesempatan bagi peserta didik untuk melakukan percobaan tatap muka apakah Ibu Herli dan Ibu Ida menyetujuinya. Pertanyaan Najwa mendapat tanggapan dari Ibu Herli dan Ibu Ida yang mengatakan bahwa mereka setuju apabila anaknya mendapat kesempatan untuk bisa melakukan pembelajaran tatap muka di sekolah.

- $\quad$ Najwa Shihab : "apakah yang Anda tangkap selama pandemi ini memang kualitas menjadi sesuatu yang perlu diperhatikan?" 
Nisa : "iya betul. Jadi sebenarnya memang sudah ada kajiannya yang menunjukkan bahwa satu tahun penutupan sekolah itu bisa menurunkan kualitas pada sekian poin."

Konteks: Najwa menanyakan kepada narasumbernya perihal kualitas manusia selama pandemi mengalami penurunan.

Dalam tuturan di atas, Najwa Shihab sebagai moderator menanyakan kepada narasumbernya yaitu Nisa terkait dengan perhatian terhadap kualitas (manusia) selama pandemi. Kemudian Nisa langsung memberikan tanggapan dengan membenarkan bahwa memang benar, sudah ada kajian yang menunjukkan bahwa satu tahun penutupan sekolah membawa dampak bagi menurunnya kualitas pada sekian poin tertentu. Itu artinya terdapat maksim kesepakatan bahwa kualitas merupakan salah satu hal yang penting untuk selalu diperhatikan terlebih pada saat masa pandemi seperti sekarang ini.

\section{Maksim Kesimpatian}

Maksim kesimpatian menghendaki kepada setiap peserta tuturan agar dapat memaksimalkan rasa simpati dan dapat meminimalisasi perasaan antipati atau penolakan di antara penutur [23]. Maksim kesimpatian menuntut setiap penutur agar dapat meningkatkan rasa kepekaan dan saling memahami perasaan yang dirasakan oleh mitra tutur. Maksim ini dapat ditunjukkan dengan memberikan ucapan selamat apabila mitra tutur dengan merasakan kebahagiaan dan mengucapkan turut prihatin apabila mitra tutur sedang merasakan kesusahan [19]. Penggunaan maksim kesimpatian dalam acara talkshow Mata Najwa dapat dilihat pada analisis data berikut.

- Wali Murid: "tapi saya kepikiran mba nana. Nanti anak saya bisa ga ya ngerjain tugasnya. Nanti mereka takutnya ketinggalan pelajaran. Akhirnya, saya bimbing juga, tapi ya gitu mereka kena marah"

Najwa Shihab : "iya iya saya membayangkan akan berat sekali memang"

Konteks: Wali murid menjelaskan keluhannya saat proses membimbing anaknya dalam melakukan kegiatan pembelajaran jarak jauh.

Data di atas, menunjukkan adanya maksim kesimpatian. Saat wali murid menyampaikan keluhannya bahwa ia sering terbawa emosi saat memberikan pengajaran dan mereka selalu terbawa pikiran jikalau nanti mereka tidak membimbing anaknya dalam kegiatan pembelajaran di rumah, maka mereka takut anaknya akan ketinggalan pelajaran. Kemudian, Najwa menanggapi dengan mengatakan bahwa ia tahu bagaimana perasaan wali murid dan ia turut membayangkan betapa beratnya wali murid saat membimbing anaknya dalam pembelajaran jarak jauh di rumah. Dengan ini Najwa menunjukkan kesimpatiannya dengan ikut membayangkan bagaimana beratnya orang tua saat membimbing anaknya belajar di sekolah.

- Ganjar: "guru relatif hampir 100\% Mbak sudah divaksin, jadi mestinya sudah selesai. Kalau ada kasus yang belum selesai "besok pagi saya vaksin”"

Konteks: Najwa Shibab mengajukan pertanyaan mengenai vaksinasi yang telah dilakukan oleh guru apakah sudah merata dilakukan, khususnya guru-guru yang ada di provinsi Jawa Tengah.

Dari tuturan di atas, Ganjar menyampaikan bahwa hampir 100\% guru telah melakukan vaksinasi, mengingat guru menjadi salah satu yang dipentingkan dan didahulukan untuk mendapatkan vaksin. Ganjar juga menambahkan bahwa saat ini vaksin sudah dilakukan pada masyarakat umum, sehingga kalau ada guru yang belum divaksin hal tersebut tentunya aneh dan patut untuk dipertanyakan. Adanya maksim kesimpatian ditunjukkan dengan kepedulian Ganjar mengenai pemberian vaksin kepada guru. Bahkan ia akan turun langsung segera memvaksin guru jika memang ada yang belum diberi vaksin yang dibuktikan dengan perkatannya "besok pagi saya vaksin".

Dari hasil analisis di atas, jika dibandingkan dengan analisis dari tiga penulis sebelumnya, yaitu Hidayat Nur Septiadi (2020) berjudul "Kesantunan Berbahasa pada Acara Talkshow Hitam Putih Trans 7 Episode Solena Chaniago Seorang Transgender dengan Biaya 1 Miliar”, Qorita Fitria 
Yuni (2013) berjudul "Kesantunan Berbahasa dalam Mata Najwa (Tinjauan Pragmatik)", dan penelitian oleh Rika Astuti, dkk (2012) berjudul "Kesantunan Berbahasa dalam Talkshow Neo Democrazy di Metro TV" memiliki persamaan dan perbedaan.

Persamaannya terletak pada fokus penelitian yang diangkatnya, yaitu sama sama menganalisis mengenai prinsip kesantunan berbahasa yang sumber datanya secara garis besar menggunakan sumber data yang bersal dari acara TV talkshow. Yang menjadikan perbedaan dari penelitian yang dilakukan oleh penulis kali ini dengan penelitian sebelumnya adalah sumber data yang digunakan penulis kali ini adalah sumber data yang berasal dari acara TV talkshow Mata Najwa yang mengangkat isu mengenai permasalahan pendidikan yang saat ini ramai menjadi perbincangan pro dan kontra dikalangan masyarakat, khususnya di masa pandemi seperti ini. Dengan bahasan mengenai isu ini pada acara talkshow Mata Najwa penulis menganalisis apakah dalam pembahasan isu yang pro dan kontra antara narasumber dengan pembawa acara dapat menciptakan sebuah tuturan yang santun.

Hasil penelitian kali ini, diperoleh sebanyak 22 penggunaan maksim prinsip kesantunan berbahasa pada acara talkshow Mata Najwa dengan persebarannya, yaitu 1) maksim kebijaksanaan sebanyak 4,2) maksim kedermawanan sebanyak 3,3) maksim penghargaan sebanyak 3,4) maksim kesederhanaan sebanyak 3,5) maksim pemufakatan sebnayak 5, dan 6) maksim kesimpatian sebanyak 4. Diharapkan penelitian ini dapat menjadi sumber informasi mengenai maksim-maksim yang ada pada prinsip kesantunan berbahasa dan dapat menjadi sumber rujukan dan referensi untuk penelitian selanjutnya.

\section{SIMPULAN}

Berdasarkan hasil analisis data di atas, dapat disimpulkan bahwa dalam acara talkshow Mata Najwa tepatnya dalam seri diskusi edisi "Coba-Coba Tatap Muka" menerapkan adanya prinsip kesantunan berbahasa, yang ditunjukkan dengan adanya pematuhan pada maksim-maksim prinsip kesantunan berbahasa yang dilakukan oleh Najwa dengan narasumbernya. Adapun hasilnya diperoleh sebanyak 22 maksim prinsip kesantunan berbahasa yang terbagi atas maksim kebijaksanaan sebanyak 4 tuturan, maksim kedermawaan sebanyak 3 tuturan, maksim penghargaan sebanyak 3 tuturan, maksim kesederhanaan sebanyak 3 tuturan, maksim pemufakatan sebanyak 5 tuturan, dan maksim kesimpatian sebanyak 4 tuturan.

\section{REFERENCES}

[1] E. N. Aini And A. P. Y. Utomo, "Analisis Tindak Tutur Lokusi dalam Video 'Jangan Lelah Belajar_B.J. Habibie’ Pada Saluran Youtube Sang Inspirasi,” Pros. Semin. Nas. Sasindo, Vol. 1, No. 2 , Pp. 11-20, 2021.

[2] Q. F. Yuni, “"Kesantunan Berbahasa dalam Mata Najwa,” Nosi, Vol. 1, No. 7, Pp. 706--716, 2013.

[3] F. A. B. S. Cahyaningrum, "Kesantunan Berbahasa Siswa dalam Konteks Negosiasi di Sekolah Menengah Atas," J. Pena Indones., Vol. 1, No. 1, Pp. 79-95, 2015.

[4] T. R. Budiwati, "Kesantunan Berbahasa Mahasiswa dalam Berinteraksi dengan Dosen di Universitas Ahmad Dahlan: Analisis Pragmatik Abstrak," 5th Urecol Proceeding, No. February, Pp. 557-571, 2017.

[5] A. N. Atiqah and Y. A. Salindri, "Prinsip Kesantunan Berbahasa Antara Pemandu Wisata Dan Wisatawan Jepang di Candi Prambanan (Kajian Analisis Pragmatik)," Kepariwisataan J. Ilm., Vol. 12, No. 01, Pp. 65-78, 2018.

[6] I. Adriana, "Analisis Bahasa SMS Mahasiswa Stain Pamekasan terhadap Dosen Menurut Prinsip Kesantunan Leech,” Nuansa, Vol. 11, No. 1, Pp. 54-76, 2014.

[7] H. N. Septiadi, "Kesantunan Berbahasa pada Acara Talk Show Hitam Putih Trans 7 Episode Solena Chaniago Seorang Transgender Dengan Biaya 1 Miliar Hidayat," J. Karakter, Vol. 1, No. May 2020, Pp. 22-33, 2020.

[8] I. Wulansafitri and A. Syaifudin, "Kesantunan Berbahasa dalam Tuturan Film My Stupid 
Boss 1," Vol. 9, No. 1, Pp. 21-27, 2020.

[9] R. Astuti And R. Syahrul, "Kesantunan Berbahasa dalam Talkshow "Neo Democrazy di Metro Tv," J. Pendidik. Bhs. Dan Sastra Indones., Vol. 1, No. 1, Pp. 443-452, 2012.

[10] A. Solihin, J. Junita, And S. Sukawati, "Analisis Kesantunan Berbahasa Pada Novel 'Me and My Heart' Karya Eva Riyanti Lubis," Parol. (Jurnal Pendidik. Bhs. Dan Sastra Indones., Vol. 2, No. 3, Pp. 339-348, 2019.

[11] S. M. Indah Widya Ningrum, Andayani, "Analisis Prinsip Kesantunan Berbahasa pada Kegiatan Diskusi Kelas Siswa SMA Negeri 7 Surakarta," J. Chem. Inf. Model., Vol. 53, No. 9, Pp. 1689-1699, 2019.

[12] B. E. Windrasari, "Dalam Acara Rumpi No Secret Di Trans Tv," Vol. 10, No. 2, Pp. 1-12, 2017.

[13] A. W. Dari, D. E. Chandra, And M. S. Sugiyati, "Analisis Kesantunan Berbahasa pada Kegiatan Pembelajaran Kelas VIII E SMP N 2 Kota Bengkulu Tahun Ajaran 2016/2017,” J. Ilm. Korpus, Vol. 1, No. 1, Pp. 10-21, 2017.

[14] S. T. F. \& A. P. Y. Utomo Ni'am, "Analisis Pematuhan dan Pelanggaran Prinsip Kesantunan Berbahasa pada Kegiatan Praktik Debat Siswa Kelas X SMA Negeri 1 Pecangaan Syahrin," J. Pendidik. Bhs. Dan Sastra Indones., Vol. 1, No. 1, Pp. 44-59, 2019.

[15] A. P. Y. Musthofa, D., \& Utomo, "Kesantunan Berbahasa Indonesia dalam Tindak Tutur Ilokusi pada Acara Rosi (Corona, Media, dan Kepanikan Publik," Vol. 14, No. April, Pp. 28 36, 2021.

[16] N. Meyra Wijayanti ${ }^{1}$, A. Purwo, And Y. Utomo ${ }^{2}$, "Analisis Tindak Tutur Direktif pada Novel Orang-Orang Biasa Karya Andrea Hirata Dan Relevansinya Sebagai Pembelajaran Bahasa Indonesia Di Sma," Maret, Vol. 3, No. 1, Pp. 15-26, 2021.

[17] A. C. Fatihah And A. P. Y. Utomo, "Analisis Tindak Tutur Perlokusi dalam Konpers Presiden Soal Covid-19 pada Saluran Youtube Cnn Indonesia," Metamorf. J. Bahasa, Sastra Indones. Dan Pengajarannya, Vol. 13, No. 1, Pp. 1-10, 2020.

[18] Y. D. I. W. B. M. U. Doko, "Kesantunan Berbahasa Dalam Kumpulan Cerita Rakyat Nusa Tenggara Timur," Retorika J. Ilmu Bhs., Vol. 3, No. 1, Pp. 159-169, 2017.

[19] L. T. Utari, "Kesantunan Berbahasa Para Peserta Diskusi dalam Gelar Wicara Mata Najwa : Kajian Pragmatik Abstrak," Vol. 8, 2021.

[20] S. P. L. ; H. T. Aulia, "Penggunaan Prinsip Kesantunan Berbahasa dalam Acara Talk Show Kick Andy Edisi 'Keluargaku Kekuatanku,"' Pap. Knowl. . Towar. A Media Hist. Doc., Vol. 2, No. 6, Pp. 12-26, 2020.

[21] N. Anggraini, N. Rahayu, And B. Djunaidi, "Kesantunan Berbahasa Indonesia dalam Pembelajaran Di Kelas X Man 1 Model Kota Bengkulu," J. Ilm. Korpus, Vol. 3, No. 1, Pp. 42-54, 2019.

[22] Junaidi; Et Al, "Kesantunan Berbahasa di dalam Pantun,” No. 1, Pp. 636-648, 2020.

[23] I. Lestari, T. Sobari, And S. Sukawati, "Analisis Prinsip Kesantunan Berbahasa pada Cerpen 'Pak Adil Mencari Keadilan' Karya Gol A Gong,” J. Pendidik. Bhs. dan Sastra Indones., Vol. 3, No. 2, Pp. 133-14-, 2020. 